\title{
O MODELO HIDROLÓGICO SWAT APLICADO À ANÁLISE DA PRODUÇÃO DE SEDIMENTOS DA BACIA DO RIO IVAÍ-PR
}

\author{
Ordilei Aparecido Gaspar de Melo' \\ Manoel Luiz dos Santos²
}

\begin{abstract}
Resumo: Esta pesquisa apresenta uma análise da produção de sedimentos da bacia hidrográfica do rio Ivaí, Paraná e a relação com as características físicas e de uso da terra, ressalta também a importância desta dinâmica nos processos

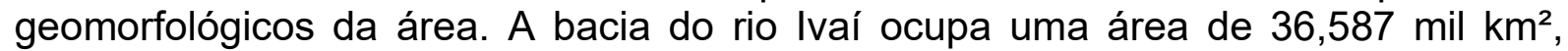
sendo abrangida por diferentes compartimentos geomorfológicos, substrato geológico complexo e solos também variados. Para a análise proposta foi utilizado o modelo SWAT (Soil and Water Assessment Tool) com base no ano de 2009. Nesse sentido, pretendeu-se verificar quais variáveis mais influenciam a produção de sedimentos na bacia. Os resultados evidenciaram maiores índices de produção de sedimentos (16,35-31,86 ton/ha) nas sub-bacias $25,23,14$ e 26 no setor médio, 3 no setor inferior e 21 no superior. Esses limiares foram influenciados, sobretudo pelos índices de escoamento superficial (384 - $573 \mathrm{~mm} / \mathrm{ano})$, os elevados índices pluviométricos e as declividades mais acentuadas.
\end{abstract}

Palavras-chave: Análise, produção de sedimentos, modelo SWAT, bacia do rio Ivaí/PR.

\section{THE SWAT HYDROLOGICAL MODEL APPLIED TO THE ANALYSIS OF SEDIMENT PRODUCTION OF THE IVAI RIVER BASIN-PR}

\begin{abstract}
This research presents an analysis of the sediment production of the river basin of the Ivaí River, Paraná and the relation with the physical and land use characteristics, also emphasizes the importance of this dynamics in the geomorphological processes of the area. The basin of the Ivaí River occupies an area of 36,587 thousand $\mathrm{km}^{2}$, being covered by different geomorphological compartments, complex geological substrate and also varied soils. For the proposed analysis, the SWAT (Soil and Water Assessment Tool) was used based on the year 2009. In this sense, it was tried to verify which variables most influence the sediment production in the basin. The results showed higher sediment yield indices (16.3531.86 tons / ha) in sub-basins 25, 23, 14 and 26 in the medium sector, 3 in the lower sector and 21 in the upper sector. These thresholds were influenced, mainly by the indices of surface runoff (384 - $573 \mathrm{~mm} /$ year), the high rainfall indexes and the more pronounced slopes.
\end{abstract}

\footnotetext{
${ }^{1}$ Secretaria de Estado da Educação do Paraná- SEED - E-mail: ordmelo@hotmail.com

${ }^{2}$ Universidade Estadual de Maringá/ GEMA - Grupo de estudos Multidisciplinares do ambiente - E-mail: mluisdossantos@gmail.com
} 
Keywords: Analysis, sediment production, SWAT model, Ivai river basin / PR.

\section{INTRODUÇÃO}

Os sedimentos produzidos em uma bacia hidrográfica e transportados pelo canal fluvial são provenientes da erosão sobre as vertentes e da erosão sobre as margens e leito do canal principal e seus tributários (KNIGHTON, 1998). A produção de sedimentos é um importante produto da dinâmica erosiva da bacia, visto que, partículas do solo são retiradas e/ou depositadas nas vertentes remodelado-as ou direcionadas até os canais fluviais influenciando no aporte de sedimentos dos mesmos.

O desenvolvimento desta pesquisa teve como foco a análise da produção de sedimentos da bacia do rio Ivaí. Apesar da importância socioeconômica e ambiental desta bacia para o estado do Paraná, poucos são os estudos sistemáticos a respeito da mesma. Este fato aumenta a importância deste estudo na medida em que este sistema fluvial ainda corre em seu leito natural e estão sendo desenvolvidos, pelo Estado do Paraná, estudos de viabilidade de implantação de usinas hidroelétricas em seu curso principal.

O estudo da produção de sedimentos se justifica pela importância que este representa para o entendimento da dinâmica erosiva da bacia hidrográfica. Os processos geomorfológicos que atuam na área de estudo demandam uma análise da bacia hidrográfica como sistema, no qual há interdependência e variabilidade espacial de interações entre as variáveis, o que resulta em comportamentos e respostas complexos.

Esta pesquisa tem como proposta analisar a produção de sedimentos na bacia do rio Ivaí e as relações dessa dinâmica com as características físicas e o uso da terra na bacia mediante a aplicação do modelo hidrológico SWAT (Soil and Water Assessment Tool) para o ano de 2009. Esta pesquisa complementará os estudos até então desenvolvidos no PGE-UEM/ GEMA, na bacia hidrográfica do rio Ivaí.

\section{A ÁREA DE ESTUDO}

A bacia hidrográfica do rio Ivaí é a segunda maior do estado do Paraná, está situada entre as coordenadas geográficas $22^{\circ} 56^{\prime} 17^{\prime \prime}$ e $25^{\circ} 35^{\prime} 27^{\prime \prime}$ de latitude sul e $50^{\circ} 44^{\prime} 17^{\prime \prime}$ e $53^{\circ} 41^{\prime} 43^{\prime \prime}$ de longitude oeste, ocupando uma área de $36,587 \mathrm{mil} \mathrm{km}^{2} \mathrm{e}$ aproximadamente $20 \%$ do território paranaense (Figura. 1). Possui um formato alongado e orientação norte-noroeste. O rio Ivaí nasce na confluência do rio dos Patos com o rio São João, na serra da Boa Esperança, nas proximidades do município de Ivaí, a uma altitude de 1120 metros e percorre uma extensão 798 km até sua desembocadura no rio Paraná, na altitude de $225 \mathrm{~m}$.

A bacia do rio Ivaí se desenvolve de um modo geral acompanhando o mergulho monoclinal das camadas paleozóicas e mesozóicas da Bacia Sedimentar do Paraná. A área da bacia é cortada por uma série de lineamentos estruturais de origem e tamanhos variados, dominadas por falhas, fraturas e lineações com direção 
preferencial NW-SE, paralela ao Arco de Ponta Grossa (CPRM apud FUJITA, 2009).

De acordo com a classificação realizada por Maack (2002), a bacia do rio Ivaí encontra-se situada no Segundo e Terceiro Planalto Paranaense. O Segundo Planalto é caracterizado por apresentar "escarpas de estratos", denominada de cuestas, configurado por um relevo suavemente ondulado, com colinas, outeiros e boqueirões, mas também paisagens de outeiros e vales junto a serra da Boa Esperança.

O Terceiro Planalto Paranaense representa o reverso da cuesta da escarpa da Serra Geral, constituída por espessos derrames de lavas basálticas e pelos arenitos da Formação Caiuá (Kr). Neste compartimento, desenvolve-se o médio e baixo curso do rio Ivaí. De acordo com Douhi (2013), no médio curso, o relevo apresenta-se suavemente ondulado a ondulado, com topos alongados, vertentes convexas, com presença de saltos e cachoeiras. Já no baixo curso, em área de domínio da Formação Caiuá, o relevo configura-se uniforme e horizontalizado de colinas convexas, caracterizado por extensas chapadas e platôs suavemente ondulados.

A bacia foi anteriormente dividida por diversos autores em três setores distintos (superior, médio e inferior) de acordo com as características geológicogeomorfológicas, esta divisão facilita os estudos do sistema fluvial, pois o mesmo pode ser analisado por setor. $\mathrm{O}$ alto curso do rio Ivaí (setor superior) atravessa as formações sedimentares complexas da Bacia do Paraná, no médio curso (setor médio) o canal sobrepõe-se às Formações Serra Geral e Caiuá e no baixo curso (setor inferior), os sedimentos inconsolidados da sua planície aluvial também na área de domínio da Formação Caiuá.

Figura 1: Localização da bacia hidrográfica do rio Ivaí com a compartimantação de acordo com as características geológico-geomorfológicas.

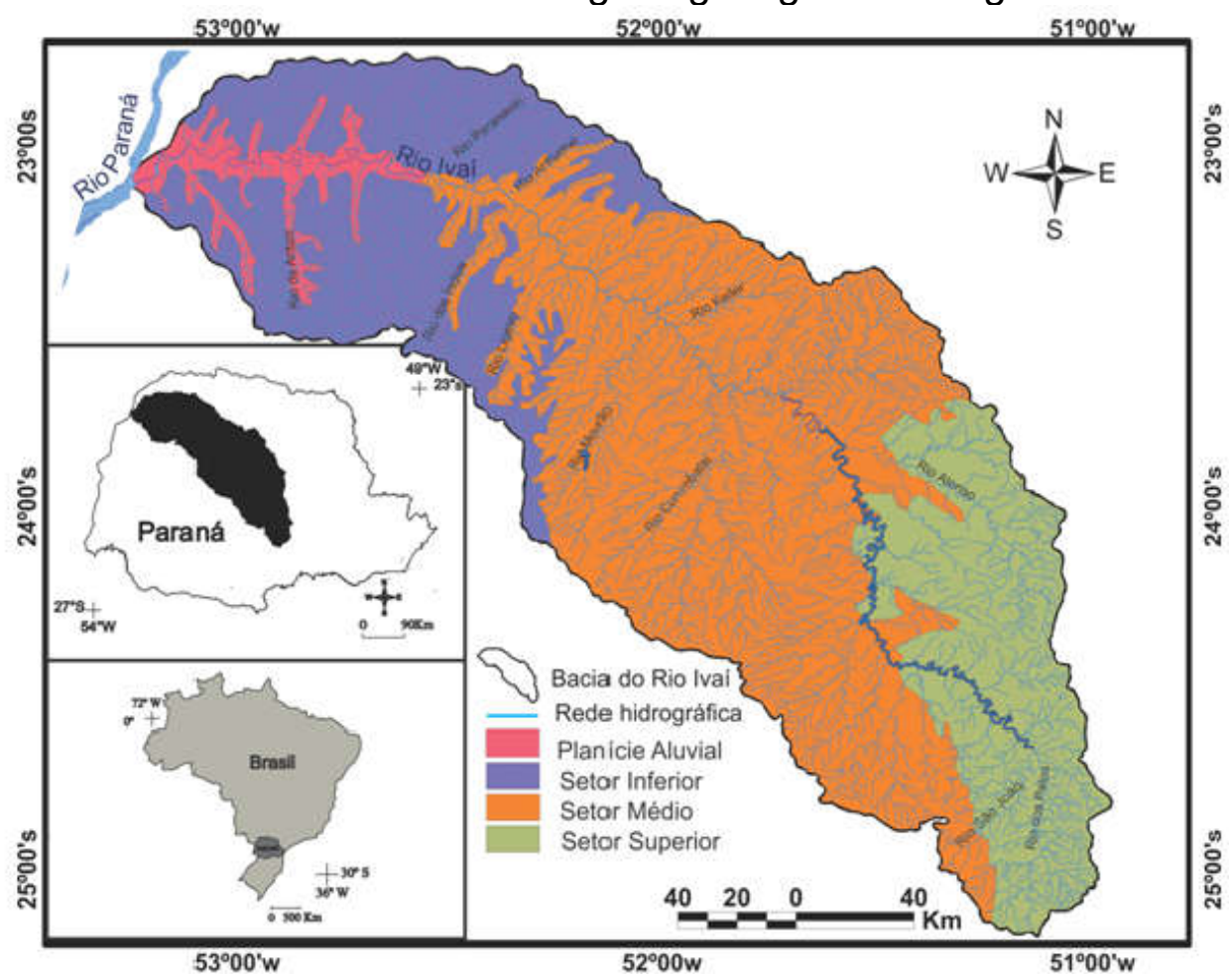

Fonte: modificado de Leli et al, (2017). 


\section{PROCEDIMENTOS METODOLÓGICOS}

No modelo SWAT a erosão causada pela chuva e pelo escoamento é computada pela Equação Universal de Perdas de Solo Modificada (MUSLE) proposta por Williams, (1975). A MUSLE é uma equação modificada da Equação Universal de perda de solo (USLE) desenvolvida por Wischmeier e Smith (1978). A USLE prevê a média anual bruta da erosão como uma função da força da chuva. Na MUSLE o fator de força da chuva é substituído pelo fator de escoamento. A equação da MUSLE é escrita na seguinte forma:

$$
\text { sed }=11,8\left(Q_{\text {sup }} \times q_{\text {pico }} \times \text { área } a_{U R H}\right)^{0,56} \times K_{E U P S} \times C_{E U P S} \times L S_{E U P S} \times P_{E U P S} \times C F R G
$$

Onde:

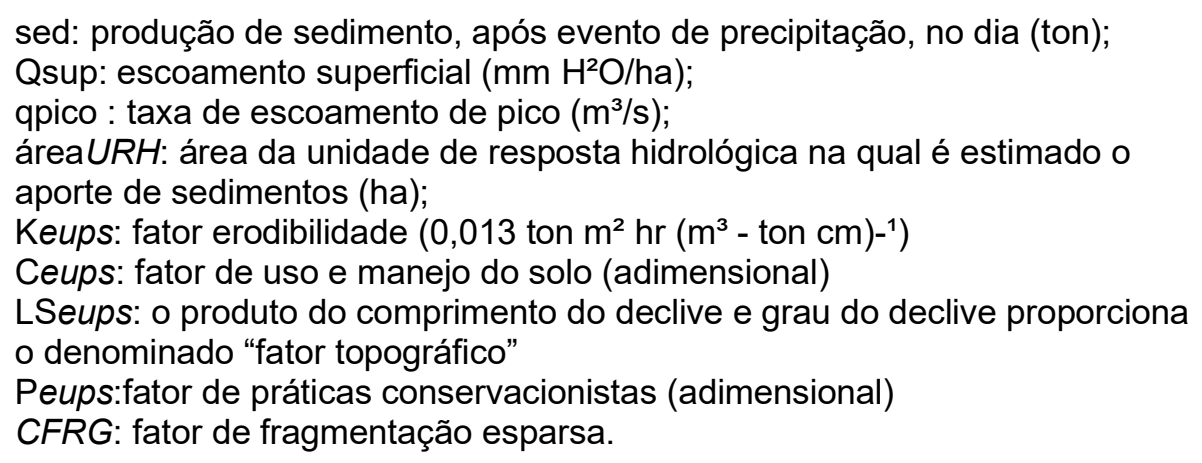

O SWAT requer a inserção do Modelo Digital de Elevação (MDE) para a delimitação de sub-bacias, os mapas de uso e cobertura da terra, mapa de tipos de solo, de declividade para reclassificação e sobreposição (overlay) e geração das Unidades de Resposta Hidrológica (HRUs) e os dados tabulares referentes às características climáticas da área para a edição do banco de dados climático do modelo (WGEN) e a simulação.

O Modelo Digital de Elevação (MDE) requerido pelo SWAT além de proporcionar o processo de delimitação das sub-bacias por meio da identificação da rede de drenagem e dos divisores de águas, também permite a extração de todos os parâmetros topográficos necessários para a execução do modelo.Para a elaboração do MDE e determinação das declividades da bacia foram utilizados dados SRTM obtidos por meio do projeto TOPODATA. Um banco de dados geomorfométricos do território nacional desenvolvido pelo INPE que traz, além do Modelo Digital de Elevação, derivações como declividade, orientação de vertentes, relevo sombreado, entre outras com resolução de 30m (VALERIANO e ROSSETTI, 2011).

Considerando a extensão da área, para montar o banco de dados referente aos solos da bacia foram utilizadas informações dominantemente secundárias. $O$ mapeamento dos solos na área de estudo foi obtido a partir do levantamento de reconhecimento de solos do estado do Paraná, Tomos I e II (EMBRAPA, 1984), com atualização para o novo Sistema Brasileiro de Classificação de Solos (EMBRAPA, 2007).

Para a classificação dos solos da área de estudo quanto aos grupos hidrológicos foi utilizado o trabalho de Sartori, (2004). O estabelecimento da condutividade hidráulica saturada dos solos considerou os valores propostos por 
Dent e Young apud Baldissera, (2005) que relaciona a classificação textural e a estrutura dos solos à condutividade hidráulica.

Para a parametrização dos dados de entrada dos solos referentes a profundidade máxima que a raiz alcança (SOL_ZMX), porosidade (ANION_EXCL), profundidade da camada (SOL_Z), densidade aparente (SOL_BD), carbono orgânico (SOL_CBN) e percentagem de argila (CLAY), silte (SILT), areia (SAND)e seixo (ROCK) foram utilizadas as informações do Levantamento de Reconhecimento de Solos do Paraná, Tomos I e II, (EMBRAPA,1984).

O valor do (SOL_ALB) ou albedo do solo de 0,17 foi estabelecido para todos os solos e é utilizado para realização do balanço energético na rotina interna do modelo SWAT. Para estimar a erodibilidade dos solos (USLE_K) foi utilizado o trabalho de Bertoni e Lombardi Neto (2005). A água disponível no solo (SOL_AWC) foi determinada observando-se os limiares propostos por Salter e Williams (1967, 1969).

Para a elaboração do mapa de uso e cobertura da terra foram utilizadas imagens do satélite LANDSAT 5/TM disponibilizadas pelo INPE, com as seguintes órbitas ponto e datas: 222/76 - 20/04/09, 223/76 - 11/04/09, 224/76 - 18/04/09, 222/77 - 04/04/09, 223/77 - 11/04/09, 222/78 - 04/04/09, 221/78 - 04/04/09. Após a classificação das imagens foram elencadas seis classes temáticas para este estudo: floresta, pastagem, corpos hídricos, culturas temporárias, solo exposto e cana de açúcar (Tabela 1).

A classificação utilizada foi a máxima verossimilhança que considera a ponderação das distâncias entre médias dos níveis digitais das classes, utilizando parâmetros estatísticos (INPE, 2003). Cada elemento a ser classificado é identificado através de características padrão. Cada classe recebeu cerca de 50 amostras de treinamento. Para compor um mosaico de imagens da bacia hidrográfica inteira foram necessárias nove cenas.

Tabela 1: Porcentagem das classes de uso e cobertura da terra da bacia do rio Ivaí para o ano de 2009.

\begin{tabular}{ll}
\hline $\begin{array}{l}\text { Uso e cobertura da terra } \\
\text { (2009) }\end{array}$ & $\begin{array}{l}\text { Área que ocupa na } \\
\text { bacia (\%) }\end{array}$ \\
Pastagem (PAST) & 62,68 \\
Floresta (FRST) & 17,56 \\
Culturas temporárias & 9,76 \\
(AGRR) & \\
Solo exposto (HRSD) & 7,46 \\
Cana de açúcar (SUGC) & 2,26 \\
Corpos hídricos (WATR) & 0,28
\end{tabular}

Para a edição do banco de dados do gerador climático do SWAT, denominado WGEN foram utilizados dados climáticos diários de precipitação, temperatura (mínima e máxima), radiação solar, velocidade de vento e umidade relativa do ar para as estações de Campo Mourão, Irati, Ivaí e Maringá fornecidos pelo INMET. Os dados das estações automáticas de Cândido de Abreu, Paranavaí e Umuarama foram solicitados junto ao SIMEPAR. Também foram utilizados dados de 
precipitação fornecidos pelo Sistema de Informação Hidrológica do Instituto de Águas do Paraná.

O arquivo de entrada com dados tabulares foi inserido no gerador climático visando a geração de dados climáticos diários requeridos pelo modelo para a simulação. As estações climáticas, seus códigos, localização e altitude podem ser visualizados na tabela 2 . O modelo SWAT exige uma série histórica de dados climáticos para a simulação, sendo assim para este trabalho foram utilizados dados da série histórica de 2004 a 2013. Para fins de complementar a pesquisa de Santos et al. (2013) , foi utilizado o ano de 2009 para a simulação. Segundo os autores, a escolha deste ano se justifica uma vez que os dados de precipitação e temperatura foram os mais completos para os postos pluviométricos e estações climatológicas.

Tabela 2: Estações climatológicas com seus respectivos códigos, latitudes, longitudes, altitudes, período dos dados analisados: * SIMEPAR, ${ }^{* *}$ INMET e Instituto de Águas do

\section{Paraná}

\begin{tabular}{|c|c|c|c|}
\hline $\mathrm{N}^{\circ}$ Código Estação & Latitude & Longitude & Altitude/ Período \\
\hline 1. 2451003 *Cândido de Abreu & $24^{\circ} 49^{\prime} 48^{\prime \prime}$ & $51^{\circ} 08^{\prime} 32^{\prime \prime}$ & 550 m/2004-2013 \\
\hline 2. 2352031 * Cianorte & $23^{\circ} 47^{\prime} 34^{\prime \prime}$ & $52^{\circ} 38^{\prime} 29^{\prime \prime}$ & 572 m/2004-2013 \\
\hline 3. 2353031 Icaraíma & $23^{\circ} 22^{\prime} 59^{\prime \prime}$ & $53^{\circ} 37^{\prime} 00^{\prime \prime}$ & 450 m/2004-2013 \\
\hline 4. 2550000 Rio dos Patos & $25^{\circ} 12^{\prime} 00^{\prime \prime}$ & $50^{\circ} 55^{\prime} 59^{\prime \prime}$ & 690 m/2004-2013 \\
\hline 5. 2352017 *Paranavaí & $23^{\circ} 04^{\prime} 59^{\prime \prime}$ & $52^{\circ} 25^{\prime} 59^{\prime \prime}$ & $480 \mathrm{~m} / 2004-2013$ \\
\hline 6. 2353008 *Umuarama & $23^{\circ} 37^{\prime} 00^{\prime \prime}$ & $53^{\circ} 22^{\prime} 00^{\prime \prime}$ & $480 \mathrm{~m} / 2004-2013$ \\
\hline 7. $83767^{* *}$ Maringá & $23^{\circ} 4^{\prime} 00^{\prime \prime}$ & 51⒐'00"' & $542 \mathrm{~m} / 2004-2013$ \\
\hline 8. $83783^{\text {**Campo Mourão }}$ & $24^{\circ} 05^{\prime} 00^{\prime \prime}$ & $52^{\circ} 36^{\prime} 00^{\prime \prime}$ & $616,4 \mathrm{~m} / 2004-2013$ \\
\hline 9. 83836 ** Irati & $25^{\circ} 46^{\prime} 00^{\prime \prime}$ & $50^{\circ} 63^{\prime} 00^{\prime \prime}$ & $836,9 \mathrm{~m} / 2004-2013$ \\
\hline 10. $83811^{* *}$ Ivaí & $25^{\circ} 00^{\prime} 00^{\prime \prime}$ & $50^{\circ} 86^{\prime} 00^{\prime \prime}$ & 808 m/2004-2013 \\
\hline
\end{tabular}

\section{RESULTADOS E DISCUSSÃO}

A análise dos resultados demonstra a complexidade que envolve a interação entre as variáveis de um sistema fluvial, que embora sejam reconhecidas e descritas na literatura evidenciam comportamentos difusos quanto às respostas dessas interações.

O Modelo Digital de Elevação gerado para a bacia do rio Ivaí (Figura 2) tem altitudes que variam de $226,9 \mathrm{~m}$ na sua foz com o rio Paraná no Terceiro Planalto Paranaense, setor inferior da bacia, até $1289,2 \mathrm{~m}$ em seu setor superior na transição entre o Segundo e o Terceiro Planalto Paranaense, essa variação se deve às características dos diferentes compartimentos morfoestruturais e morfoesculturais identificados por Santos et al, (2006).

Os parâmetros topográficos tais como a declividade e comprimento de rampa são determinantes para estimar a produção de sedimentos na escala da bacia hidrográfica. Assim, torna-se imprescindível para os modelos distribuídos de base física como o SWAT delinear as sub-bacias e extrair a rede de drenagem. De acordo 
com Calijuri et al. (1998), a representação do sistema de drenagem da bacia hidrográfica e seu grau de ramificação permite caracterizar a velocidade do escoamento, e, consequentemente, a propagação dos sedimentos ao longo da mesma.

Figura 2 - Modelo Digital de Elevação da bacia do Ivaí com as sub-bacias delimitadas pelo modelo SWAT

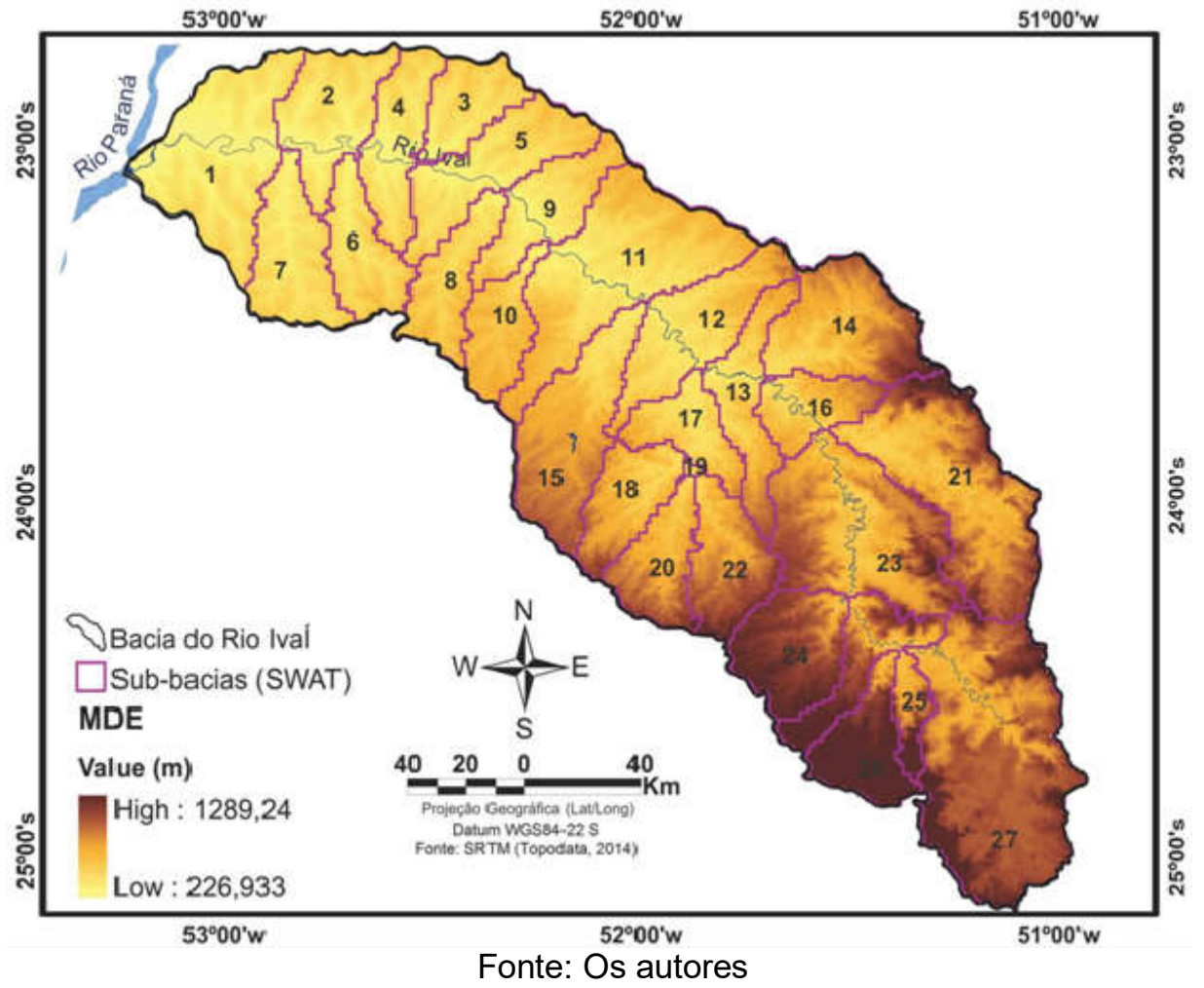

As declividades na bacia do rio Ivaí variam de $0 \%$ a $30 \%$ superando esse limiar em algumas porções, isso se deve parte à geologia da área e aos processos geomorfológicos que nela atuaram. No setor superior abrangida pelo arcabouço geológico complexo do Segundo Planalto Paranaense, onde dominam as rochas sedimentares da Bacia do Paraná, as declividades são mais pronunciadas, em algumas porções ultrapassam os $30 \%$.

No Terceiro Planalto, área de domínio das rochas eruptivas básicas, setor médio da bacia, o relevo apresenta menores amplitudes altimétricas com predomínio das baixas declividades, entre 0 e $12 \%$ podendo chegar a $20 \%$ em alguns segmentos de cabeceiras de drenagem e interflúvios dos tributários localizados nessa porção. No setor inferior, área de domínio da Formação Caiuá as declividades apresentam variação de 0 a $12 \%$, na porção representada pela planície aluvial do rio Ivaí por se tratar de um ambiente deposicional com pouca variação espacial de altitude, as declividades também têm pouca variação de 0 a 6\% (Figura 3). 
Figura 3: Declividade da bacia do rio Ivaí.

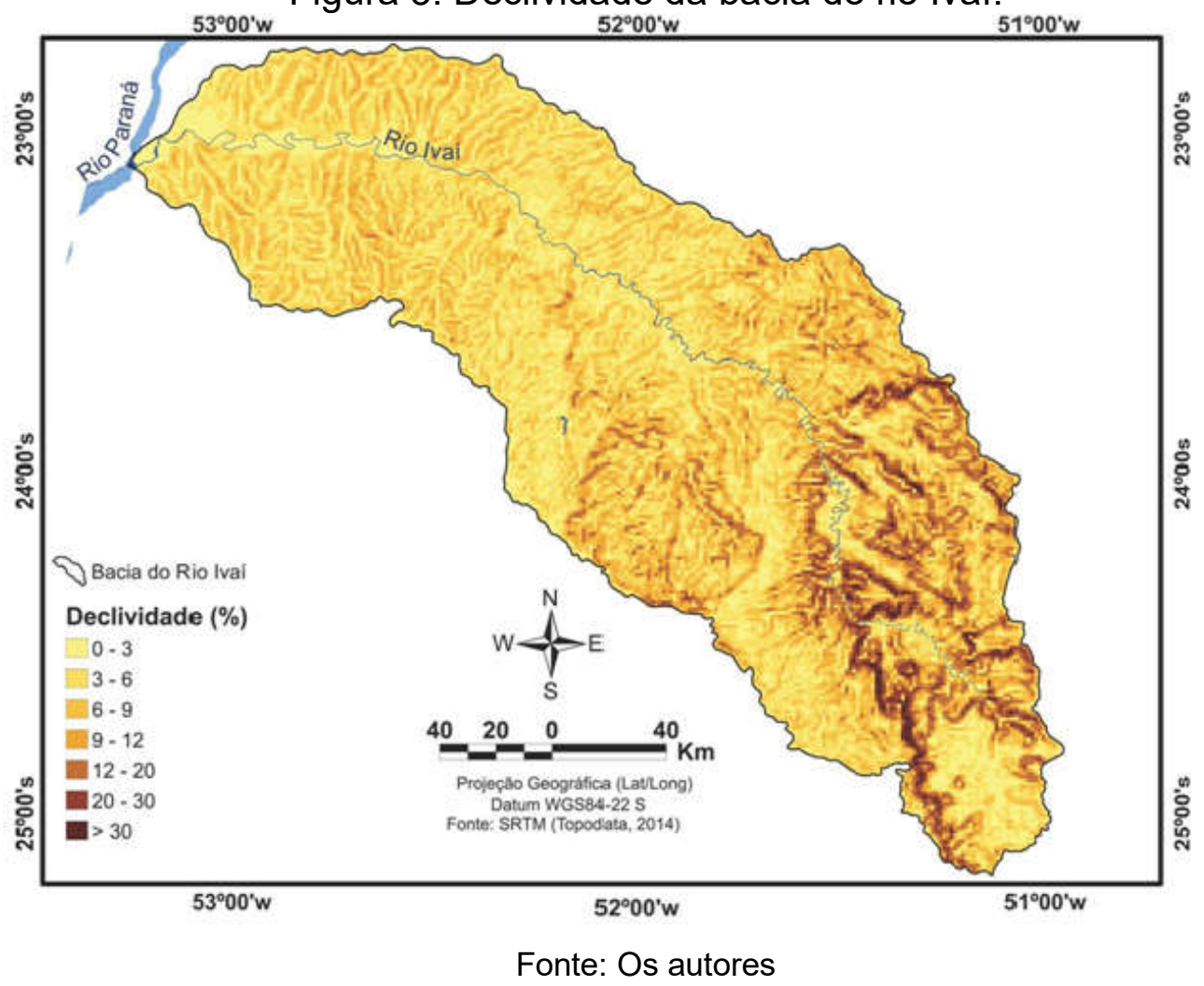

Os solos encontrados na área de pesquisa foram agrupados de acordo com as suas classes (Argissolos, Latossolos, Cambissolos, Gleissolos, NeossoloLitólico, NeossoloFlúvico, Nitossolos e Organossolos), e textura, que variou de média, argilosa, arenosa, arenosa/média e média/argilosa (Figura 4).

No setor médio da bacia a interação entre o substrato geológico, a geomorfologia e os processos geomorfológicos associados deram origem a uma maior heterogeneidade dos tipos de solos em comparação com os demais setores da bacia. Segundo Douhi (2013), neste setor predominam os Nitossolos de textura argilosa, que dominam as vertentes e os topos mais estreitos e dissecados. Os NeossolosLitólicos de textura média, normalmente estão associados aos locais mais dissecados e de maiores declividades. Os Latossolos de textura média e argilosa, associados à ocorrência dos arenitos, ocupando os topos de alguns interflúvios e também os Argissolos de textura arenosa/média, que recobrem segmentos de vertentes nas áreas onde o substrato geológico é constituído por arenitos da Formação Caiuá.

No setor inferior da bacia do Ivaí, na área de ocorrência dos arenitos da Formação Caiuá, ocorrem os Latossolos de textura média e osArgissolos de textura arenosa/média. De acordo com Santos et al. (2008) ocorrem ainda na planície aluvial do rio Ivaí, solos pouco desenvolvidos do tipo NeossoloFlúvico que recobre os terraços, a planície e algumas ilhas e algumas manchas de Gleissolos e Organossolos. 
Figura 4: Tipos de solo da bacia do rio Ivaí.

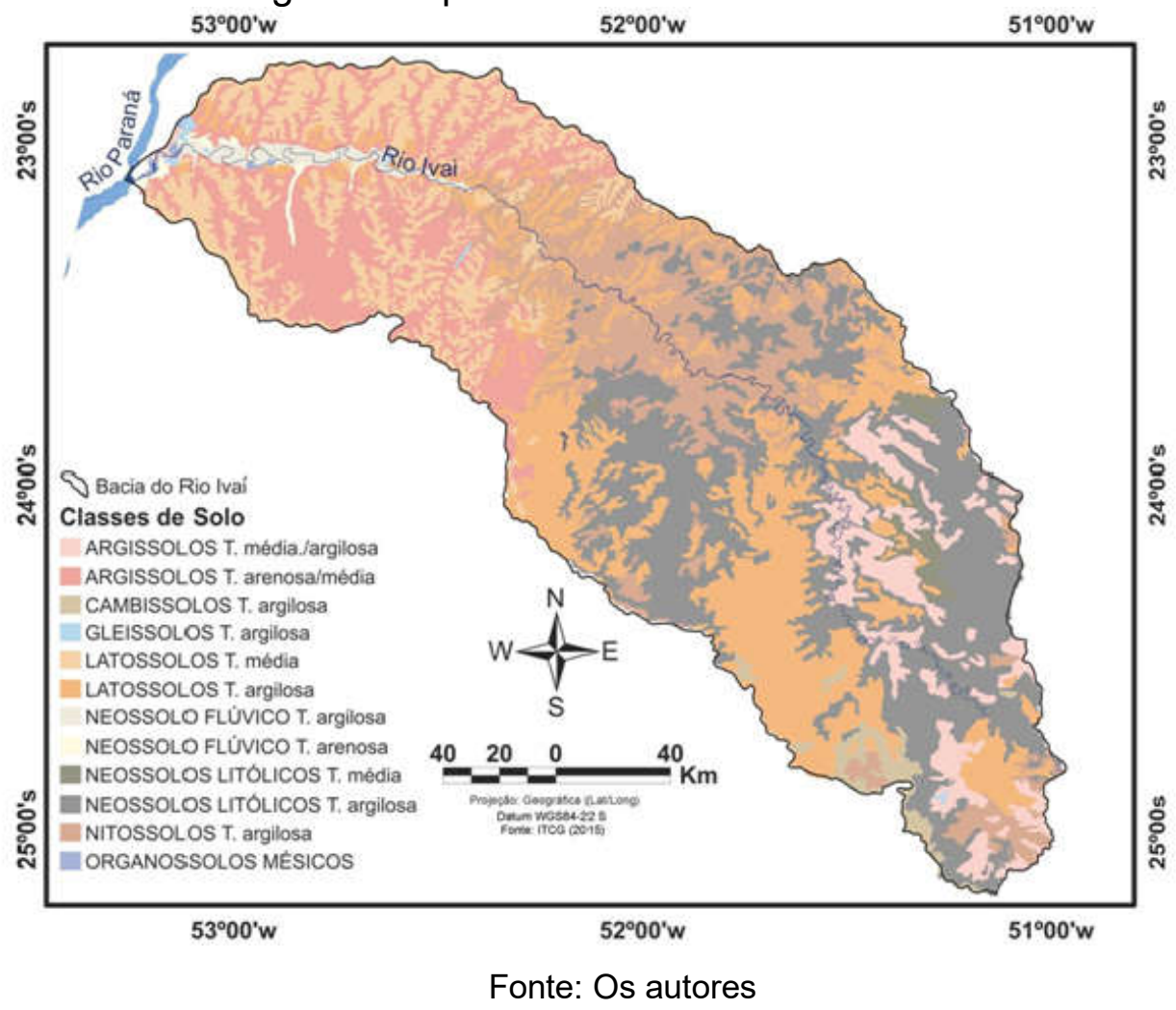

A figura 5 apresenta o mapa da distribuição espacial da precipitação acumulada (média) para o ano de 2009 paras as sub-bacias delimitadas durante o processo de subdivisão da área requerida pelo modelo SWAT. Esse resultado foi alcançado por meio da edição do banco de dados climático (WGEN) inserindo-se as informações de dez estações climatológicas que se localizam no interior e no entorno da área territorial representada. O modelo atribui a cada sub-bacia os dados de precipitação da estação mais próxima.

O trecho que representa o setor inferior (sub-bacias 1, 2, 4, 5, 6, 7 e 8) e o setor médio/inferior e médio da bacia do rio Ivaí (sub-bacias 9 e 11) apresentam os menores índices pluviométricos por se localizarem em um setor de baixas altitudes (319,5 - 424,8 m em média), numa faixa de transição do clima tropical para o subtropical com precipitações médias anuais $<1.525,1-1.824,6 \mathrm{~mm} / \mathrm{ano}$. As subbacias 3 e 10, localizadasno setor inferior da bacia são uma exceção aos menores índices observados apresentando volumes pluviométricos de 1.977,7-2007.2 mm/ano.

As sub-bacias $12,13,15,17,18,19,20$ e 22 localizadas no setor médio apresentam índices pluviométricos de $1.824,6$ a $2.007,2 \mathrm{~mm} / \mathrm{ano}$. No setor médio/superior e superior da bacia as sub-bacias 14, 16, 21, 23, 24, 25 e 27 apresentam os mais expressivos volumes pluviométricos, de 2.007,2 a 2.008,4 $\mathrm{mm} /$ ano. Estas sub-bacias estão localizadas nas porções com as maiores altitudes da bacia (608.4 - 1.010,8 m em média), e, segundo Andrade (2003); Baldo (2006), sofrem influência da orografia, ou seja, com a elevação da altitude do relevo se elevam também os índices pluviométricos.

Andrade e Nery (2011), realizaram a delimitação dos grupos homogêneos de distribuição espacial da pluviometria da bacia do rio Ivaí e concluíram que os 
mesmos praticamente seguem os contornos das curvas de nível do relevo, o que indica um efeito orográfico fortemente influenciador da ocorrência de chuvas. De acordo com Douhi (2013), na bacia não são identificados períodos secos que possam configurar um regime sazonal, embora os maiores volumes pluviométricos se concentrem nos períodos da primavera e do verão, influenciados pelos sistemas convectivos tropicais que atuam mais nesse período.

Figura 5: Distribuição espacial dos índices pluviométricos da bacia do rio Ivaí para o ano de 2009.

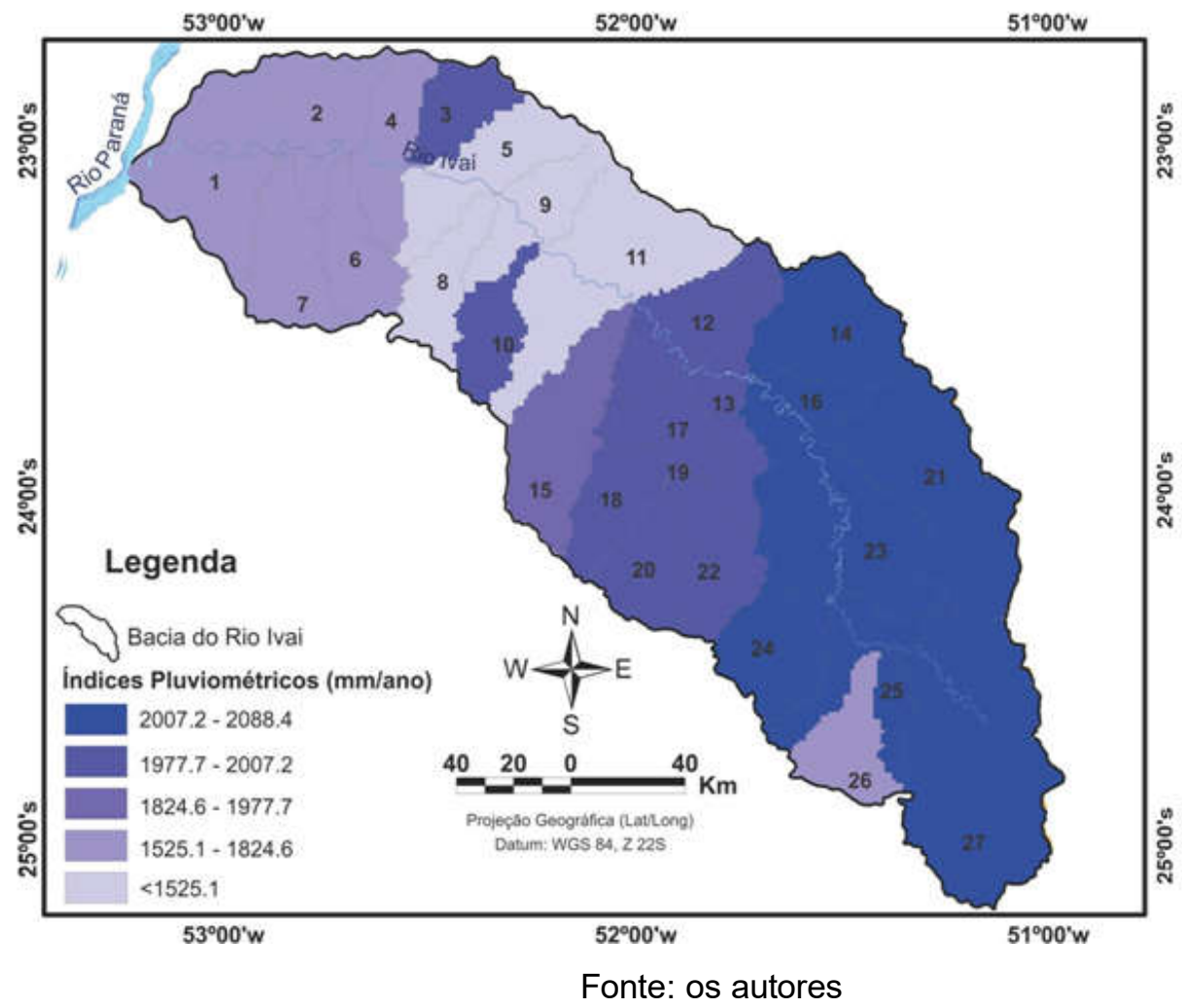

\section{ANÁLISE DO ESCOAMENTO SUPERFICIAL}

A análise do escoamento superficial da bacia do rio Ivaí evidencia distintos comportamentos ao longo da área de estudo (Figura 6). Os índices de escoamento encontrados situaram-se entre 262 e $713 \mathrm{~mm} / \mathrm{ano}$ com os setores médio (sub-bacias $12,15,16$ e 24) e inferior (sub-bacias 3 e 10) da bacia apresentando os índices mais acentuados (573 - $713 \mathrm{~mm} / \mathrm{ano}$ ). Esta variabilidade do escoamento superficial na bacia pode estar diretamente relacionada a interação entre as propriedades de precipitação e evapotranspiração, cobertura do solo, uso da terra e dos tipos de solos da área, conforme já preconiza Smith e Goodrich (2005). 
Figura 6: Mapa síntese de escoamento superficial da bacia do rio Ivaí para o

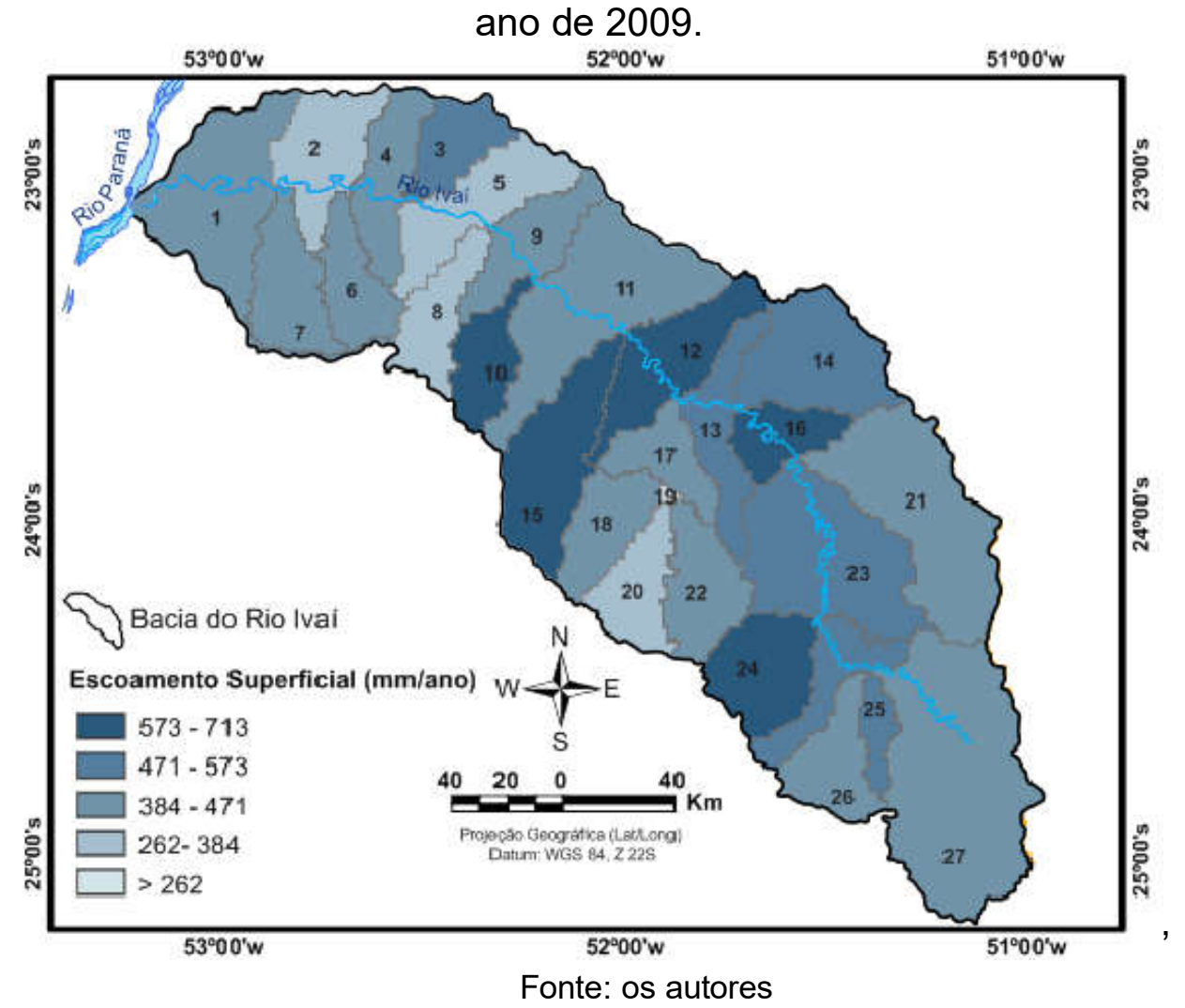

\section{ANÁLISE DA PRODUÇÃO DE SEDIMENTOS}

Bortolotto (2011), analisando a distribuição espacial para a produção de sedimentos na bacia do rio Cunha em Santa Catarina com o modelo SWAT para o ano de 2001 obteve limiares que variam de 0,34 a 327 (ton/ha). Em sua pesquisa a autora observou que as duas sub-bacias que mais produziram sedimento ( 3 e 6 ) foram as caracterizadas por Cambissolos, elevado escoamento superficial $(1.142,00$ e $1.121,00 \mathrm{~mm}$, respectivamente) e declividades acentuadas. O uso do solo para cultivos agrícolas e pastagens colabora expressivamente com estes processos por não proporcionar resistência à passagem da água pelo solo e, em geral, haver baixa infiltração de água nas camadas de solo ocupadas por estes usos.

A análise da produção de sedimentos gerados pelo modelo SWAT para a bacia do rio Ivaí evidencia distintos comportamentos ao longo da área de estudo, com valores que variam de 0,56 a 31,86 ton/ha (Figura 7). Esses limiares foram influenciados pelos índices pluviométricos, características dos solos, declividade, escoamento superficial e uso e cobertura da terra. 
Figura 7 - Produção de sedimentos (ton/ha) por sub-bacia para o ano de 2009.

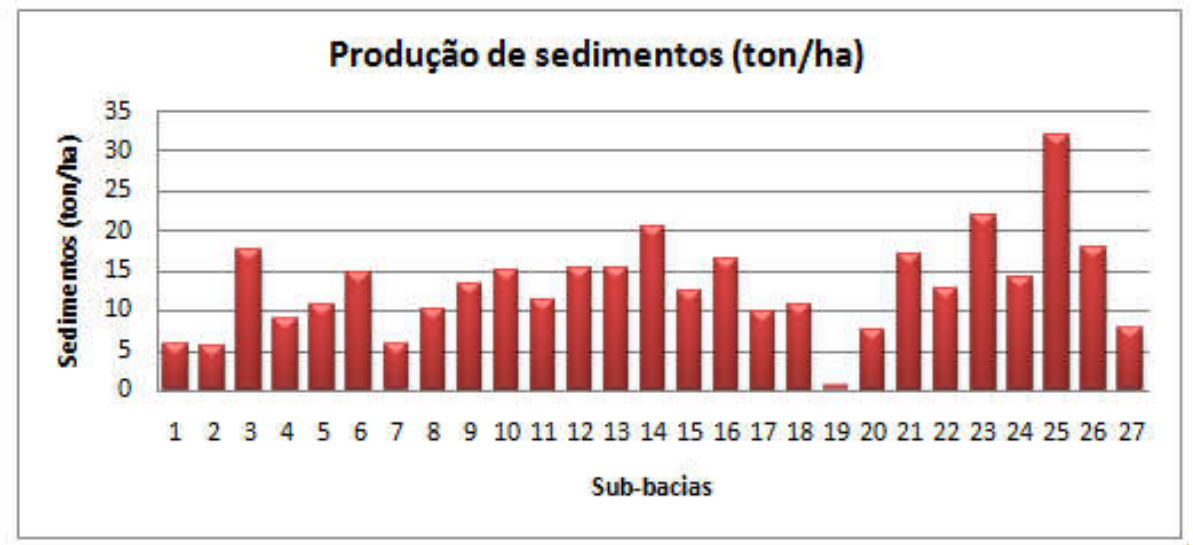

Fonte: Os autores

A figura 8 apresenta a distribuição espacial da produção de sedimentos (ton/ha) na bacia do rio Ivaí. De maneira geral, as sub-bacias que apresentaram as maiores taxas de produção de sedimentos por ordem de produção foram as de número $25,23,14,26,3$ e 21 . Abaixo segue a descrição da produção de sedimentos das sub-bacias por setor.

A sub-bacia 21, localizada no setor superior apresentou índices de produção de sedimentos da ordem de 16,35 - 21,78 ton/ha em área de contexto geológico complexo do Segundo Planalto na qual predominam os Neossolos Litólicos, Argissolos de textura média/argilosa, Latossolos de textura argilosa, algumas manchas pouco expressivas de Nitossolos e Cambissolos de textura argilosa. Estes limiares foram influenciados pelo uso da terra composto, sobretudo por pastagens, as declividades acentuadas podendo ultrapassar os $30 \%$, os elevados índices pluviométricos de 2.007,2 a 2.088,4 mm/ano sobre solos com baixos valores de condutividade hidráulica e índice de escoamento superficial de 384 a 471 mm/ano.

O setor médio abrange as sub-bacias $11,12,13,14,15,16,17,18,19,20$, 22, 23, 24, 25 e 26, as mesmas apresentaram índices de produção de sedimentos que variam de 5,78 - 31,86 ton/ha. No entanto, para este setor apenas serão analisadas as sub-bacias que apresentaram os mais acentuados valores de produção de sedimentos.

A sub-bacia 25 localizada em uma área de transição entre o contexto geológico do Segundo Planalto Paranaense e aFormação Serra Geral no Terceiro Planalto foi a que apresentou a maior produção de sedimentos de 21,78 - 31,86 ton/ha. Nessa área os solos são os Neossolos Litólicos, Latossolos de textura argilosa, Argissolos de textura média/argilosa e Cambissolos. Uso e cobertura da terra de pastagem e áreas pontuais de floresta, declividades que variam de $0->30 \%$ com predominância das declividades de $20-30 \%$, elevados índices pluviométricos de 2.007,2 a 2088,4 mm/ano e elevado escoamento superficial (471 - $573 \mathrm{~mm} / \mathrm{ano})$.

As sub-bacias 14, 23 e 26 apresentaram produção de sedimentos de 16,35 21,78 ton/ha. Estas sub-bacias estão localizadas em contextos geológicos distintos (contexto geológico complexo do Segundo Planalto Paranaense e Formação Serra Geral no Terceiro Planalto), onde os solos predominates são Latossolos de textura argilosa, Argissolos de textura média/argilosa, Neossolos Litólicos, Nitossolos e Cambissolos. O uso e cobertura da terra é principalmente de pastagens, floresta e áreas pontuais de culturas temporárias e declividades de 0 - $>30 \%$ com 
predominância das declividades de 12 - 20\%. Os índices pluviométricos das subbacias são de 1.824,6 -2.085,7 mm/ano e escoamento superficial de $384-573$ $\mathrm{mm} / \mathrm{ano}$.

As sub-bacias 12, 13, 15, 16, 22 e 24, também localizadas no setor médio da bacia apresentaram valores médios de produção de sedimentos, da ordem de 11, 34 - 16, 35 ton/ha. Esses limiares podem ter sido influenciados pelos elevados índices pluviométricos (1977,7-2088,4 mm/ano), pelas características de uso da terra, sobretudo de pastagens e culturas temporárias, floresta e áreas pontuais de cana de açúcar e solo exposto que provém uma baixa proteção do solo, as declividades de 0 - 30\% com predominância das declividades de $9-12 \%$,os mais altos índices de escoamento superficial (573-713 mm/ano) sobretudo nas sub-bacias 12, 15, 16 e 24 e devido aos baixos valores de condutividade hidráulica dos solos destas sub-bacias.

A sub-bacia 3 localizada no setor inferior apresentou índices de produção de sedimentos de 16,35 - 21,78 ton/ha. Esta sub-bacia está localizada em área abrangida pelos arenitos de Formação Caiuá. A área também apresentou índices elevados de escoamento superficial de 471 a $573 \mathrm{~mm} / \mathrm{ano}$, os solos são do tipo Latossolos de textura média e Argissolos de textura arenosa/média que são solos sabidamente erodíveis como descrito por Sala, (2005), Prado e Nóbrega (2005), Souza (2010), entre outros. As declividades variam entre 0 e $12 \%$, com uso da terra formado por pastagens e solo exposto e índices pluviométricos entre 1.977,7-2.007,2 $\mathrm{mm} / \mathrm{ano}$. A suscetibilidade natural dos solos à erosão como já descrito na literatura, em que se pese os altos valores de erodibilidade, bem como os elevados índices pluviométricos, o uso da terra e os índices de escoamento superficial foram os fatores determinantes para o índice de produção de sedimentos observados na área.

As sub-bacias 4, 6, 9, apresentaram índices de produção de sedimentos de 11, 34 - 16, 35 ton/ha. Estes limiares podem ter sido influenciados pelo uso da terra de pastagens, culturas temporárias, cana de açúcar e solo exposto, índice pluviométrico que varia de $<1.225,1-1.824,6$ e índice de escoamento superficial de $384-471 \mathrm{~mm} / a n o$. Associa-se a isto também a presença de Latossolos de textura média e Argissolos de textura arenosa/média, solos comprovadamente suscetíveis à erosão e as declividades de $0-12 \%$.

As sub-bacias 5, 8 apresentaram valores de produção de sedimentos de 5,78 - 11,34 ton/ha. O uso do solo é de pastagens, solo exposto e cana de açúcar, os índices pluviométricos são os mais baixos para a bacia $(<1.225,1 \mathrm{~mm} / \mathrm{ano})$ e 0 escoamento superficial é de 262 - $384 \mathrm{~mm} / \mathrm{ano}$.

As sub-bacias 1, 2 e 7 apresentaram os mais baixos valores de produção de sedimentos, de 0,56 - 5,78 ton/ha. Embora estas sub-bacias estejam na área de abrangência dos arenitos de Formação Caiuá, onde predominam Latossolos de textura arenosa/média e Argissolos de textura média, as precipitações anuais são menos pronuncidas (1.525,1-1.824,6 mm/ano), o escoamento superficial é de 262 $471 \mathrm{~mm} / \mathrm{ano}$ e uso e cobertura da terra de pastagens e áreas pontuais de cultuas temporárias, solo exposto, cana de açúcar e florestas. 
Figura 8 - Produção de sedimentos por sub-bacia para o ano de 2009.

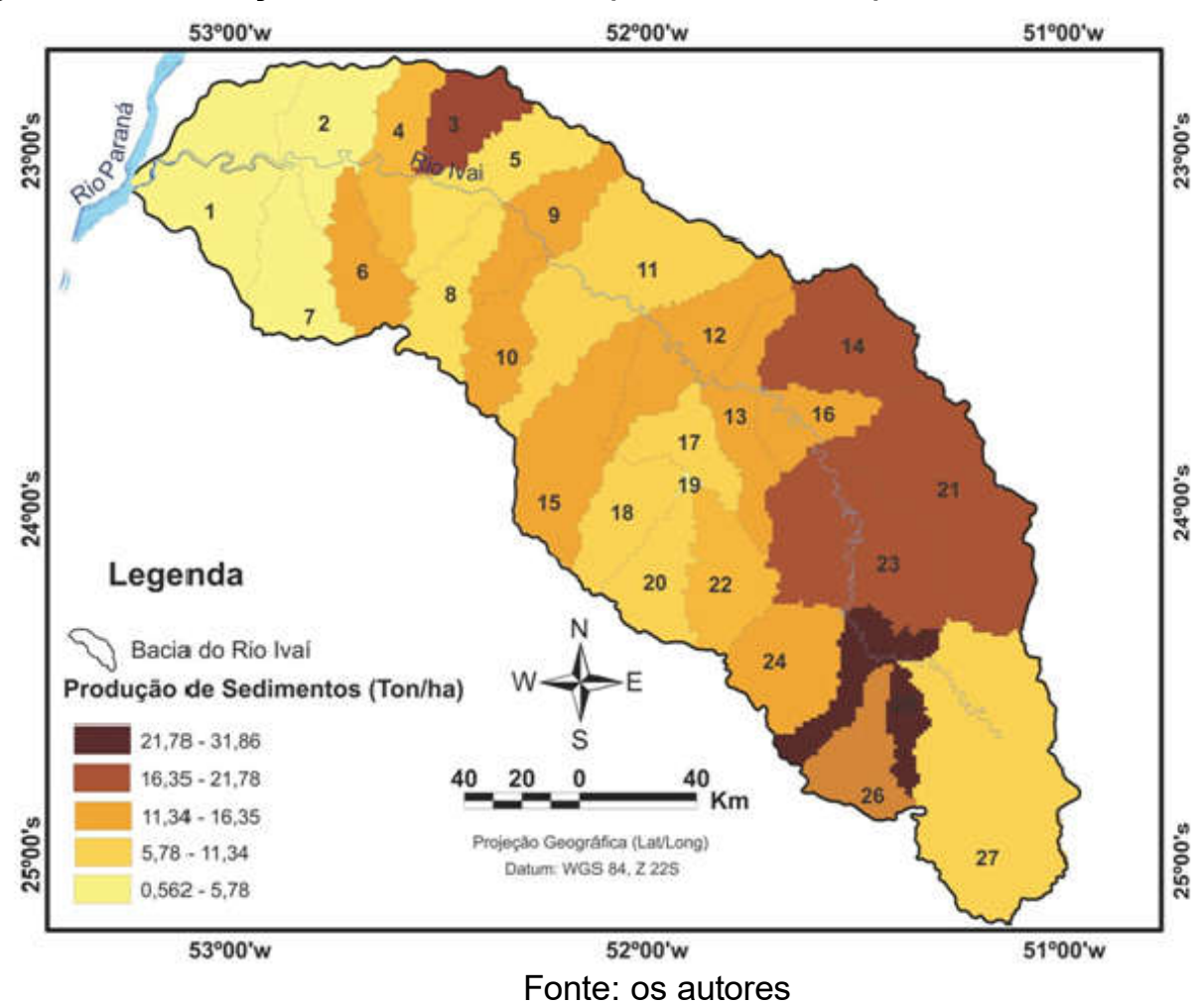

Prado e Nóbrega (2005), analisaram a perda de solos na bacia do rio Ipiranga em Cidade Gaúcha e notaram que as áreas sujeitas às maiores perdas de solo por erosão laminar são aquelas com cultivo de cana-de-açúcar e mandioca, os autores afirmam que a pastagem é o tipo de uso menos prejudicial quanto à erosão laminar para a área estudada. A cultura temporária é caracterizada pela sazonalidade no cultivo, sendo assim, o solo fica um período coberto e outro descoberto, dependendo da época do ano, do manejo e da quantidade de chuvas, as perdas de solo podem ser acentuadas ou atenuadas, por essa razão Ross (1994), classifica as culturas de ciclo curto como de forte risco a fragilidade aos processos erosivos.

Enquanto que na pesquisa de Prado e Nóbrega (2005), a bacia analisada possui solos homogêneos no que diz respeito ao material de origem, verificou-se que o uso do solo influenciou fortemente os índices de produção de sedimentos. Os resultados de produção de sedimentos para a bacia do rio Ivaí obtidos por meio do modelo SWAT demonstram uma forte influência do escoamento superficial, mesmo sobre solos com propriedades e material de origem distintos, soma-se a isto os elevados índices pluviométricos juntamente com as declividades, que, em algumas porções das sub-bacias podem superar os 30\% (Tabela 3). Sendo assim entende-se que estas variáveis em conjunto seriam as responsáveis por acentuar a produção de sedimentos em algumas porções da área de estudo.

Tabela 3 - Síntese dos índices de precipitação, escoamento superficial, características de uso e cobertura da terra, geologia, solos e declividade das sub-bacias com maior produção de sedimentos (ton/ha) para o ano de 2009 na bacia do rio Ivaí.

\begin{tabular}{c|c|c|c|c|c|c|c}
\hline $\begin{array}{c}\text { Setor } \\
\text { (sub- } \\
\text { bacia) }\end{array}$ & $\begin{array}{c}\text { Produção } \\
\text { de }\end{array}$ & $\begin{array}{c}\text { Precipitação } \\
\text { sedimentano) }\end{array}$ & $\begin{array}{c}\text { Escoa- } \\
\text { mento } \\
\text { superfi- }\end{array}$ & $\begin{array}{c}\text { Uso e } \\
\text { cobertura } \\
\text { da terra }\end{array}$ & $\begin{array}{c}\text { Geologia } \\
\text { dade }(\%)\end{array}$ & Solos \\
\hline
\end{tabular}


O modelo hidrológico...

\begin{tabular}{|c|c|c|c|c|c|c|c|}
\hline & (ton/ha) & & $\begin{array}{c}\text { cial } \\
\text { (mm/ano } \\
\text { ) }\end{array}$ & & & & \\
\hline $\begin{array}{l}\text { Superior } \\
(21)\end{array}$ & $16,35-21,78$ & $\begin{array}{l}2007.2- \\
2088.4\end{array}$ & $384-471$ & Pastagem. & $\begin{array}{l}\text { Contexto } \\
\text { geológico } \\
\text { complexo do } \\
\text { Segundo } \\
\text { Planalto. }\end{array}$ & $\begin{array}{l}\text { Neossolos } \\
\text { Litólicos, } \\
\text { Argissolos de } \\
\text { textura } \\
\text { média/argilosa, } \\
\text { Latossolos de } \\
\text { textura argilosa, } \\
\text { Nitossolos e } \\
\text { Cambissolos. } \\
\end{array}$ & $\begin{array}{l}0- \\
>30 \% .\end{array}$ \\
\hline Médio (25) & $\begin{array}{l}21,78- \\
31,86\end{array}$ & $2007.2-2088.4$ & $471-573$ & $\begin{array}{l}\text { Pastagem e } \\
\text { áreas } \\
\text { pontuais de } \\
\text { floresta. }\end{array}$ & $\begin{array}{l}\text { Transição } \\
\text { :contexto } \\
\text { geológico do } \\
\text { Segundo } \\
\text { Planalto } \\
\text { Paranaense e o } \\
\text { Terceiro } \\
\text { Planalto } \\
\text { (Formação } \\
\text { Serra Geral) }\end{array}$ & $\begin{array}{l}\text { Neossolos } \\
\text { Litólicos, } \\
\text { Latossolos de } \\
\text { textura argilosa, } \\
\text { Argissolos de } \\
\text { textura } \\
\text { média/argilosa e } \\
\text { Cambissolos. }\end{array}$ & $\begin{array}{l}0- \\
>30 \%\end{array}$ \\
\hline $\begin{array}{l}\text { Médio (14, } \\
23 \text { e } 26)\end{array}$ & $16,35-21,78$ & $\begin{array}{l}1525.2- \\
2088.4\end{array}$ & $\begin{array}{l}262- \\
471\end{array}$ & $\begin{array}{l}\text { Pastagens, } \\
\text { floresta e } \\
\text { áreas } \\
\text { pontuais de } \\
\text { culturas } \\
\text { temporári- } \\
\text { as. }\end{array}$ & $\begin{array}{c}\text { Formação Serra } \\
\text { Geral. }\end{array}$ & $\begin{array}{c}\text { Latossolos de } \\
\text { textura argilosa, } \\
\text { Argissolos de } \\
\text { textura } \\
\text { média/argilosa, } \\
\text { Neossolos } \\
\text { Litólicos, } \\
\text { Nitossolos e } \\
\text { Cambissolos. }\end{array}$ & $\begin{array}{l}0- \\
>30 \% .\end{array}$ \\
\hline $\begin{array}{l}\text { Médio (12, } \\
13,15,16, \\
22 \text { e } 24)\end{array}$ & $\begin{array}{l}11,34-16, \\
35\end{array}$ & $1977.7-2088.4$ & $384-713$ & $\begin{array}{l}\text { Pastagens } \\
\text { e culturas } \\
\text { temporári- } \\
\text { as, floresta } \\
\text { e áreas } \\
\text { pontuais de } \\
\text { cana de } \\
\text { açúcar e } \\
\text { solo } \\
\text { exposto. }\end{array}$ & $\begin{array}{l}\text { Formação Serra } \\
\text { Geral. }\end{array}$ & $\begin{array}{l}\text { Latossolos de } \\
\text { textura argilosa, } \\
\text { Nitossolos, } \\
\text { Neossolos } \\
\text { Litólicos, } \\
\text { Cambissolos. }\end{array}$ & $0-30 \%$ \\
\hline Inferior (3) & $\begin{array}{l}16,35- \\
21,78\end{array}$ & $\begin{array}{l}2007.2 \\
-2088.4\end{array}$ & $471-573$ & $\begin{array}{l}\text { Pastagens } \\
\text { e solo } \\
\text { exposto. }\end{array}$ & $\begin{array}{l}\text { Formação } \\
\text { Caiuá. }\end{array}$ & $\begin{array}{l}\text { Latossolos de } \\
\text { textura média e } \\
\text { Argissolos de } \\
\text { textura } \\
\text { arenosa/média. }\end{array}$ & $0-12 \%$ \\
\hline $\begin{array}{l}\text { Inferior }(4, \\
6 \text { e } 9)\end{array}$ & $\begin{array}{l}11,34-16 \\
35\end{array}$ & $\begin{array}{l}<1225.1-1824 . \\
6\end{array}$ & $384-471$ & $\begin{array}{l}\text { Pastagens, } \\
\text { culturas } \\
\text { temporári- } \\
\text { as, cana de } \\
\text { açúcar e } \\
\text { solo } \\
\text { exposto. } \\
\end{array}$ & Formação Caiuá & $\begin{array}{l}\text { Latossolos de } \\
\text { textura média e } \\
\text { Argissolos de } \\
\text { textura } \\
\text { arenosa/média. }\end{array}$ & $0-12 \%$ \\
\hline $\begin{array}{l}\text { Inferior (1, } \\
2 \text { e } 7)\end{array}$ & $0,56-5,78$ & $\begin{array}{l}1525.1- \\
1824.6\end{array}$ & $\begin{array}{l}262- \\
471\end{array}$ & $\begin{array}{l}\text { Pastagens } \\
\text { e áreas } \\
\text { pontuais de } \\
\text { cultuas } \\
\text { temporári- } \\
\text { as, solo } \\
\text { exposto, } \\
\text { cana de } \\
\text { açúcar e } \\
\text { florestas. }\end{array}$ & Formação Caiuá & $\begin{array}{l}\text { Latossolos de } \\
\text { textura } \\
\text { arenosa/média e } \\
\text { Argissolos de } \\
\text { textura média. }\end{array}$ & $0-12 \%$ \\
\hline
\end{tabular}

$\mathrm{Na}$ análise dos produtos e processos geoambientais tem-se a interferência de um número muito grande de variáveis do meio físico e antrópico, que interagem com vários graus de dependência (KIRKBY, 1980). Para diferentes condições locais (uso da terra, clima, solos e relevo) e em diferentes escalas, os processos dominates não 
são os mesmos (GRUNWALD e FREDE, 1999). Sendo assim, assume-se que a produção de sedimentos é influenciada por uma série de fatores que possuem grande variabilidade espacial e diferentes graus de interdependência o que confere à análise deste processo uma considerável complexidade.

A análise dos índices de produção de sedimentos com o SWAT demonstrou que as sub-bacias em que os índices foram mais acentuados, o escoamento superficial, as declividades e os volumes pluviométricos estiveram entre os mais acentuados evidenciando a sensibilidade do modelo quanto a estes parâmetros. Nessas sub-bacias o uso da terra é principalmente composto por pastagens e culturas temporárias que provém baixa proteção aos solos.

Quando se compara as figuras 6 e 8 nota-se que ambas apresentam relações espaciais. Pode-se ressaltar também uma dependência das variáveis de entrada, tanto para o escoamento superficial quanto para a produção de sedimentos (declividade, uso e cobertura da terra, propriedades dos tipos de solo e clima), porém o estado final, ou seja, a síntese dos processos pode ser alcançada por meio de interrelações complexas envolvendo essas variáveis. Isso ocorre, pricipalmente devido a variabilidade espacial que algumas delas apresentam. Sendo assim, uma variável pode, direta ou indiretamente influenciar e/ou ser influenciada pelo processo que se busca representar. A diferença, nesse caso, é que o escoamento superficial equivale ao processo, e a produção de sedimentos, ao produto inerente à sua dinâmica.

\section{CONSIDERAÇÕES FINAIS}

Nesta pesquisa foi possível realizar uma avaliação das características físicas e de uso e cobertura da terra da bacia hidrográfica do rio Ivaí, e os resultados dessa interação no que se refere à produção de sedimentos.

Os resultados obtidos por meio da aplicação do modelo SWAT para a produção de sedimentos na bacia (ton/ha) mostraram que sub-bacias localizadas nos três setores $(25,23,14$ e 26 no setor médio, 3 no setor inferior e 21 no superior) conforme a figura 8 , apresentaram as maiores taxas. Observou-se que as variáveis que mais influenciam na produção de sedimentos foram: escoamento superficial, os elevados índices pluviométricos e as declividades, o que leva a crer que o escoamento superficial, representado no modelo pelo fator $\mathrm{CN}$, é uma variável que ocasiona incremento na produção de sedimentos em algumas porções da bacia, porém associada a outras variáveis também importantes.

A má distribuição das estações climáticas também pode ter influenciado nos resultados, pois grandes áreas da bacia não foram cobertas pelos registros dos dados climáticos, principalmente o setor médio e como o modelo considera a estação mais próxima seria importante que cada uma das vinte e sete sub-bacias geradas pelo modelo tivessem uma estação em sua área.

Embora os maiores valores de produção de sedimentos estejam principalmente associados ao escoamento superficial, aos elevados índices de precipitação e às declividades, essas variáveis interagem com as características dos solos, uso e cobertura da terra tornando a análise complexa. Tal fato mostra a interdependência entre as variáveis, visto que a ocorrência da produção de sedimentos não pode ser determinada por variáveis isoladas e/ou por meio de uma única variável. 
Assume-se nesta pesquisa que a produção de sedimentos é fortemente influenciada por uma série de variáveis que, em conjunto, determinam a intensidade do processo e sua importância como agente erosivo na bacia. Explicar a dinâmica ambiental da paisagem por meio da aplicação de modelos não é tarefa fácil, pois esta dinâmica possui interdependências intrínsecas que em muitos casos não se explicam por si só, por vezes envolvendo grande complexidade de interrelações entre os elementos (variáveis).

\section{AGRADECIMENTOS}

Ao PGE-UEM - Programa de Pós-Graduação em Geografia da Universidade Estadual de Maringá. Ao GEMA - Grupo de Estudos Multidisciplinares do Ambiente e à SEED - Secretaria de Estado da Educação do Paraná.

\section{REFERÊNCIAS}

ANDRADE, A. R. Variabilidade da precipitação pluviométrica da bacia hidrográfica do rio Ivaí - PR. Dissertação (Mestrado em Análise Regional e Ambiental) Departamento de Geografia, Universidade Estadual de Maringá, Maringá, 2003

ANDRADE, A. R.; NERY, J. T. Análise Sazonal e Espacial da Precipitação Pluvial na Bacia Hidrográfica Do Rio Ivaí - Paraná. Boletim de Geografia, Maringá, v. 29, n. 2, 2011. p. 107-121.

BALDO, M. C. Variabilidade pluviométrica e a dinâmica atmosférica na bacia hidrográfica do rio Ivaí. Tese (Doutorado em Geografia) Universidade Estadual Paulista, Presidente Prudente, 2006.

BALDISSERA, G. C. Aplicabilidade do Modelo de Simulação Hidrológica SWAT (Soil and Water Assessment Tool), para a Bacia Hidrogéfica do Rio Cuiabá/MT. Dissertação (Mestrado em Física e Meio Ambiente) - Programa de Pós-Graduação em Física e Meio Ambiente, Universidade Federal do Mato Grosso, Cuiabá, 2005.

BERTONI, J.; LOMBARDI NETO, F. Conservação do solo. 5. ed. São Paulo: Ícone, 2005. $355 \mathrm{p}$.

BORTOLOTTO, N. L. Avaliação Hidrossedimentológica da Bacia do Rio Cunha, Município de Rio Dos Cedros, Santa Catarina com o Modelo SWAT. TCC (Graduação em Engenharia Sanitária e Ambiental). Universidade Federal de Santa Catarina. Florianópolis, 2011.

CALIJURI, M. L.; MEIRA, A. D.; PRUSKI, F. F. Geoprocessamento Aplicado aos Recursos Hídricos. In. Congresso Brasileiro de Engenharia Agrícola. Poços de Caldas. Anais. Lavras: UFLA/SBEA. 1998. P. 200-225.

DOUHI, N. Regime e Sistemas de Controle das Cheias do Baixo Ivaí e Cartografia das Áreas Inundáveis.Tese (Doutorado em Geografia) Universidade Estadual de Maringá, Maringá, 2013. 
EMBRAPA. Sistema Brasileiro de Classificação de Solos, Embrapa Solos. Rio de Janeiro - Rj, 2006.

EMBRAPA. Levantamento de reconhecimento dos solos do Estado do Paraná tomo I e II. Boletim técnico. Londrina: EMBRAPA/SNLCS/IAPAR, 1984. 791p.

FUJITA, R. H. O Perfil Longitudinal do Rio Ivaí e sua Relação com a Dinâmica do Fluxo. Dissertação (Mestrado em Geografia) - Departamento de Geografia, Universidade Estadual de Maringá, Maringá, 2009.

GRUNWALD, S.; FREDE, H. G. Using the Modifield Agricultural Non-point Source Pollution Model in Germany Watersheds. Catena. v 37, 1999. p. 319-328.

INPE - Instituto Nacional de Pesquisas Espaciais. 2003. Disponível em: http://www.dgi.inpe.br. Acesso: em 12 de setembro de 2014.

KNIGHTON, D., Fluvial forms \& processes.Arnold, 383p, 1998.

KIRKBY, M. J. Modeling water erosion processes. In:KIRKBY, M. J.; MORGAN, R. P. C. Soil erosion, New York:John Wiley \& Sons, 1980. p. 182-213.

LELI, I. T.; STEVAUX, J. C.; CREMON. E.H.; NÓBREGA, M.T.River Functioning Analysis from Suspended Sediment and Water Discharge Study: The Case of the IvaiRiver,Southern Brazil. Revista Brasileira de Geomorfologia. v. 18. $n$ 1. 2017. p. 125-141.

MAACK, H., Geografia Física do Paraná. Secretaria da Cultura e do Esporte do Governo do Estado do Paraná. Ed. José Olympio Editora S.A., 2002. 450p.

PRADO, J. P. B.; NÓBREGA, M. T.Determinação de perdas de solo na Bacia Hidrográfica do Córrego Ipiranga em Cidade Gaúcha, Estado do Paraná, com aplicação da Equação universal de perdas de solo (EUPS). Acta Scientiarum. Technology. Maringá, v. 27, n. 1, p. 33-42, 2005.

ROSS, J. L. S. Análise empírica da fragilidade dos ambientes naturais e antropisados. In: Revista do departamento de Geografia, FFLCH/ USP. São Paulo, 1994.

SALA, M. G. Análise integrada dos elementos físicos, de uso e ocupação da bacia do Ribeirão Maringá - PR: Para fragilidade ambiental dos solos. Dissertação (mestrado em Geografia), Departamento de Geografia-Programa de PósGraduação-UEM-PR, 2005.

SALTER, P.J.; WILLIAMS, J.B. The influence oftexture on the moisture characteristics of soils. IV. A method of estimating the available water capacitiesof profiles in the field. Journal of Soil Science. 1967, vol.18, p. 174-181.

SALTER, P.J.; WILLIAMS, J.B. The influence of texture on the moisture characteristics of soils. V. Relationships between particle size composition and 
moisture contents at the upper and lower limits of available water. Journalof Soil Science. 1969. vol. 20, p. 126-131.

SANTOS, L. J. C et al, Mapeamento geomorfológico do estado do Paraná. Revista Brasileira de Geomorfologia. Ano 7, $n^{\circ} 2,2006$.

SANTOS, M. L.; STEVAUX, J. C.; GASPARETTO, N. V. L.; SOUZA FILHO, E. E. Geologia e Geomorfologia da Planície Aluvial do Rio Ivaí em seu Curso Inferior.Rev. Bras. Geomorfologia, v 9. n 1. 2008, p 23-34.

SANTOS, M. L.; MORAIS. E. S.; SILVEIRA, H.; ALVES, F. C. Estudo do escoamento superficial na bacia hidrográfica do rio Ivaí, Paraná, Brasil. Revista Brasileira de Geomorfologia. v. 14, n 3, 2013.SARTORI, A. Avaliação da Classificação Hidrológica do Solo para a Determinação do Excesso de Chuva do Método do Serviço de Conservação do Solo dos Estados Unidos. Dissertação de Mestrado Faculdade de Engenharia Civil, Arquitetura e Urbanismo - Universidade Estadual de Campinas.Campinas, 2004.

SMITH, R. E.; GOODRICH, D. C. Rainfall Excess Overland Flow. In: Encyclopedia of Hydrological Sciences. Edited by M G Anderson. John Wiley \& Sons, Ltd. 2005. p 1707-1718.

SOUZA. V. Estimativa de perdas de solo por erosão laminar na Bacia do Córrego Pinhalzinho II com suporte degeoprocessamento. Dissertação (Mestrado em Geografia) - Departamento de Geografia, Universidade Estadual de Maringá, Maringá, 2010.

VALERIANO, M. M.; ROSSETI, D. F. Topodata: Brazilian full coverage refinement of SRTM data. AppliedGeography. Ed 32. 2011, p. 300-309.

WICHMEIER, W. H.; SMITH, D.D.Predicting rainfall erosion losses: a guide to conservation planning. USDA. Maryland/EUA, 1978.

WILLIAMS, J. R. Sediment-yield prediction with Universal Equation using RunoffEnergy Factor. Transactions of the ASAE. 1975. v. 12, 100-103. 